\title{
Effect of thermal insulation and feeding treatments on early spring honey bee queen rearing
}

\author{
R. E. Omar; E.E. Nowar; M. M. Khattab; A. A. El-Berry and Eman, H. Abdel Salam \\ Plant protection Dept., Fac. Agric. Moshtohor, Benha Univ., Egypt.
}

\begin{abstract}
These experiments were conducted at the apiary of Faculty of Agriculture, Moshtohor, Benha Univ., during early spring of two successive years 2013 and 2014 to estimate the effect of wintering and feeding treatments on honey bee queen rearing. Twenty-four colonies (12 F1 Carniolan bees and 12 F1 Italian bees) were used, each group was divided in to 2 groups one of them 6 hives coated with thermal insulator, 3 colonies were covered with thermal insulator and the other were in normal Langstroth hive. Results indicated that F1 Italian bees are more better than F1 Carniolan bees in all tested queen rearing parameters (number of queen cells; length of queen cells; number of emerging new queens and queens fresh weight) during the two years of study. Data also indicated that feeding honey bee colonies with pollen substitute and sugar syrup affected positively on all queen rearing parameters and gave a good morphological virgin queens.
\end{abstract}

Keywords: Apis mellifera L., queen rearing, wintering, feeding.

\section{Introduction}

Queen rearing began when the brood nest was congested and nectar and pollen were abundant, obtained. March was the maximum month for queen cups production (Ismail, 2001). The fed colonies were active in building more queen cups than unfed ones and higher building queen cups in March (ElWaseef, 2002). Also, Shoreit et al. (2002) found that the maximum total of queen cells and queen cups was found during February-April period or swarming period.

There were clearly significant differences between the all feeding bee colonies with diets and control in the mean of worker brood area during the experimental period of February and March (Abd ElWahab, 2016).

Honey bee (Apis mellifera L.) colonies need pollen and nectar to fuel foraging flights, generate heat to thermoregulate their nest and to rear brood. Nectar is a carbohydrate source, while pollen supplies the bees with the protein, lipids, vitamins and minerals needed to rear larvae (Manning, 2001). In early spring before pollen and nectar are available or at other times of the year when these materials are in short supply, supplementary feeding may help the colony survive or make it more populous and productive (Standifer, 1973).

The possibility of improving the efficiency of beekeeping by maximizing honey production, crop pollination, to overcome pesticide damage and produce strong colonies for package-bee production, lies in the development of an effective pollen substitute to feed the colonies when pollen is in scarce (Dadant, 2000).

Since queens cannot be reared during every season, beekeepers are often unable to obtain queens at critical times of the year, especially in early spring. Thus, the reliable storage of queens from when they are reared until they are needed for re-queening is of great importance (Morse, 1979).

In dearth period because of less floral rewards, supplement feeding is necessary for maintenance of bee population. Different pulse flour has been used by several workers as a protein feed for bees (Dastouri and Sis, 2007).

The quality of the queen bee determines the benefits received from honey bee colony as through the queen, via its progeny, the productivity, temperament and behavior of the colony can be manipulated by the beekeeper. Various environmental factors affect the quality of the queen bees, as well as the rearing season and meteorological conditions influenced the rate of queen development (Mahbobi et al., 2012).

This research aimed to estimate the effect of wintering and feeding treatments on honey bee queen rearing parameters (number of queen cells; length of queen cells; number of emerging new queens and queen's fresh weight) during the two years of study.

\section{Materials and Methods}

These experiments were conducted at the apiary of Faculty of Agriculture, Moshtohor, Benha Univ., during early spring of two successive years 2013 and 2014 to estimate the effect of wintering and feeding treatments on honey bee queen rearing.

\section{Honeybee colonies}

Twenty four honey bee colonies were used for this experiment ( 9 colonies F1 Italian bees and 9 colonies F1 Carniolan bees). Each group were divided into three groups one of them (3 colonies) were received the pollen substitute and sugar solution, the second group (3 colonies) was received the pollen substitute and sugar solution coated with 
thermal insulator while the third group (3 colonies) were received sugar solution only as control. The same groups were used for queen rearing with grafting method (Laidlaw, 1979) during July month (Corn season).

\section{Pollen substitutes}

The composition of pollen substitute was as the following; Soybean flour (0.5): the chemical compositions of Soybean flour determined by Hammad (2000) as follows: humidity 6.58\%, protein $50.88 \%$, fat $5.41 \%$, fiber $6.54 \%$ and ash $6.73 \%$. Dried Brewer's yeast (0.5): the chemical compositions of Dried Brewer's yeast determined by Atallah (1975) as follows: humidity 9.5\%, crude protein $40.5 \%$, other extracts $1.5 \%$ and ash $6.25 \%$ in addition to vitamin B1, B2 and nicotinic acid. Milk
(0.25): cow's milk contains, on average, $3.4 \%$ protein $3.6 \%$ fat, $4.6 \%$ lactose, $0.7 \%$ minerals and water $87.5 \%$ (Jensen,1995). Powdered sugar. All materials were mixed with honey, citrus juice; volatile oils and antibiotics.

\section{Queen rearing}

The dray grafting method was used in this experiment in wax cubs. The percentage of successful queen cups was calculated after virgin queen emerging. This experiment was carried out every month from February to September during the two years of study. The virgin queens which produced from the previous experiment were put in small wooden cages then number of queen cells; length of queen cells; number of emerging new queens and queens fresh weight was measured.

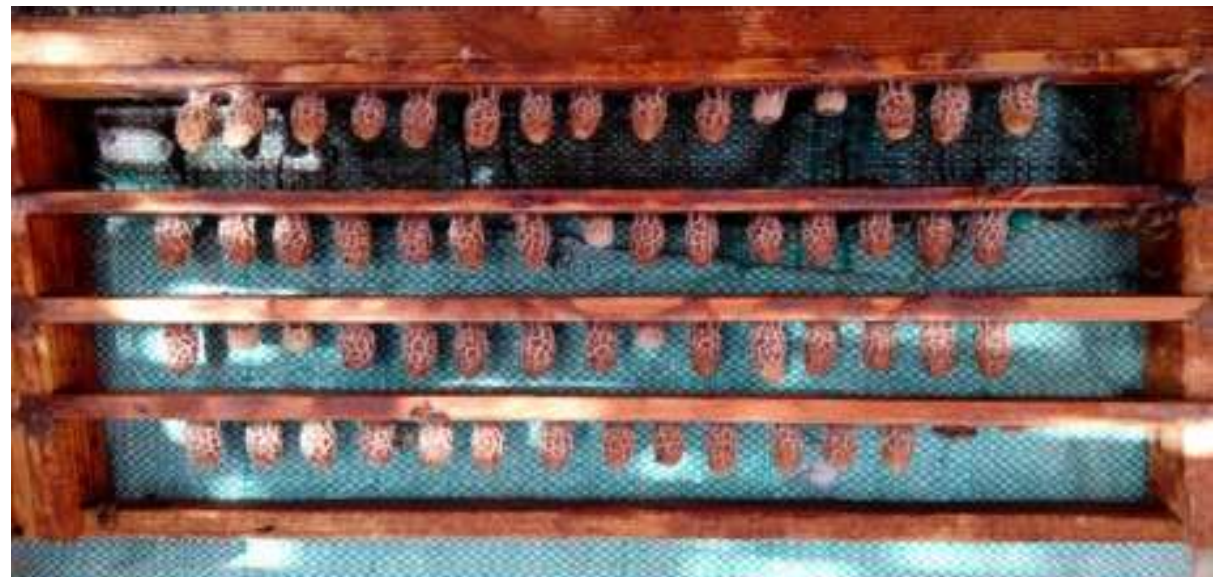

Photo 1. Queen cells from grafting method

\section{Results and Discussion}

Effect of wintering and feeding treatments on honey bee queen rearing

Data presented in Tables (1\&2) graphically illustrated by figs. (1\&2) it was clearly that F1 Italian bees is more better than F1 Carniolan bees in all tested queen rearing parameters (number of queen cells, length of queen cells, number of emerging new queens and queens fresh weigh) during the two years of study. Data also indicated that feeding honey bee colonies with pollen substitute and sugar syrup affected positively on all queen rearing parameters and gave a good morphological virgin queens. Data also indicated that covering hives with thermo insulator during winter season make honey bee colonies more ability for queen rearing and increasing the most tested queen rearing parameters during the two years of study.

These data were harmony with Mahbobi et al. (2012) who indicated that the supplemental feeding significantly increased most morphological characteristics of reared queens. Also, Krol et al. (1992) reported that queens reared in colonies fed with sugar syrup supplemented with vitamin B, recorded $11 \%$ heavier and have more $6 \%$ overiols. 
Table 1. Effect of wintering and feeding treatments on honey bee queen rearing by grafting method during March 2013.

\begin{tabular}{|c|c|c|c|c|c|c|c|c|c|}
\hline \multirow[b]{2}{*}{ Treatment } & & \multicolumn{4}{|c|}{ F1 Italian bees } & \multicolumn{4}{|c|}{ F1 Carniolan bees } \\
\hline & & $\begin{array}{c}\text { No. of } \\
\text { queen } \\
\text { cells }\end{array}$ & $\begin{array}{c}\text { Length of } \\
\text { queen cells } \\
(\mathrm{cm} .)\end{array}$ & $\begin{array}{c}\text { No. of } \\
\text { emerging } \\
\text { queens }\end{array}$ & $\begin{array}{c}\text { Queens's } \\
\text { fresh weight } \\
\text { (g.) }\end{array}$ & $\begin{array}{l}\text { No. of } \\
\text { queen } \\
\text { cells }\end{array}$ & $\begin{array}{c}\text { Length of } \\
\text { queen cells } \\
(\mathrm{cm} .)\end{array}$ & $\begin{array}{c}\text { No. of } \\
\text { emerging } \\
\text { queens }\end{array}$ & $\begin{array}{c}\text { Queens's } \\
\text { fresh weight } \\
\text { (g.) }\end{array}$ \\
\hline \multirow{3}{*}{$\begin{array}{l}\text { Control } \\
\text { Wintering } \\
\text { treatment }\end{array}$} & & 27 & 1.52 & 22 & 0.16 & 25 & 1.5 & 21 & 0.16 \\
\hline & Only sugar syrup & 38 & 1.71 & 31 & 0.18 & 34 & 1.7 & 28 & 0.17 \\
\hline & Pollen substitute & 54 & 2.1 & $\mathbf{5 0}$ & 0.2 & 51 & 1.9 & 48 & 0.19 \\
\hline
\end{tabular}

Table 2. Effect of wintering and feeding treatments on honey bee queen rearing by grafting method during March 2014.

\begin{tabular}{|c|c|c|c|c|c|c|c|c|c|}
\hline \multirow[b]{2}{*}{ Treatment } & & \multicolumn{4}{|c|}{ F1 Italian bees } & \multicolumn{4}{|c|}{ F1 Carniolan bees } \\
\hline & & $\begin{array}{c}\text { No. of } \\
\text { queen } \\
\text { cells }\end{array}$ & $\begin{array}{c}\text { Length of } \\
\text { queen cells } \\
\text { (cm.) }\end{array}$ & $\begin{array}{c}\text { No. of } \\
\text { emerging } \\
\text { queens } \\
\end{array}$ & $\begin{array}{c}\text { Queens's } \\
\text { fresh weight } \\
\text { (g.) } \\
\end{array}$ & $\begin{array}{c}\text { No. of } \\
\text { queen } \\
\text { cells }\end{array}$ & $\begin{array}{c}\text { Length of } \\
\text { queen cells } \\
(\mathrm{cm} .) \\
\end{array}$ & $\begin{array}{c}\text { No. of } \\
\text { emerging } \\
\text { queens } \\
\end{array}$ & $\begin{array}{c}\text { Queens's } \\
\text { fresh weight } \\
\text { (g.) }\end{array}$ \\
\hline \multirow{3}{*}{$\begin{array}{l}\text { Control } \\
\text { Wintering } \\
\text { treatment }\end{array}$} & & 31 & 1.61 & 27 & 0.16 & 28 & 1.60 & 25 & 0.16 \\
\hline & Only sugar syrup & 41 & 1.77 & 36 & 0.17 & 39 & 1.71 & 34 & 0.18 \\
\hline & Pollen substitute & 52 & 2.20 & 51 & 0.22 & 51 & 2.00 & 46 & 0.19 \\
\hline
\end{tabular}




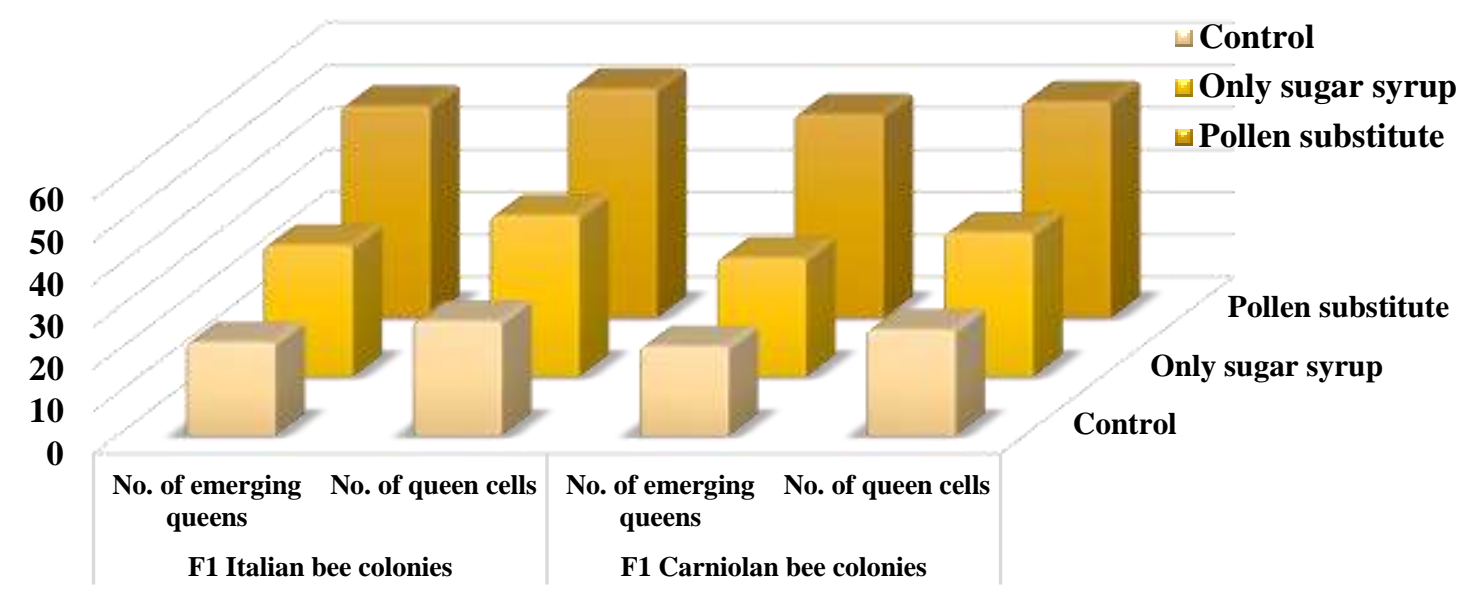

Fig 1. Effect of wintering and feeding treatments on queen rearing during March 2013

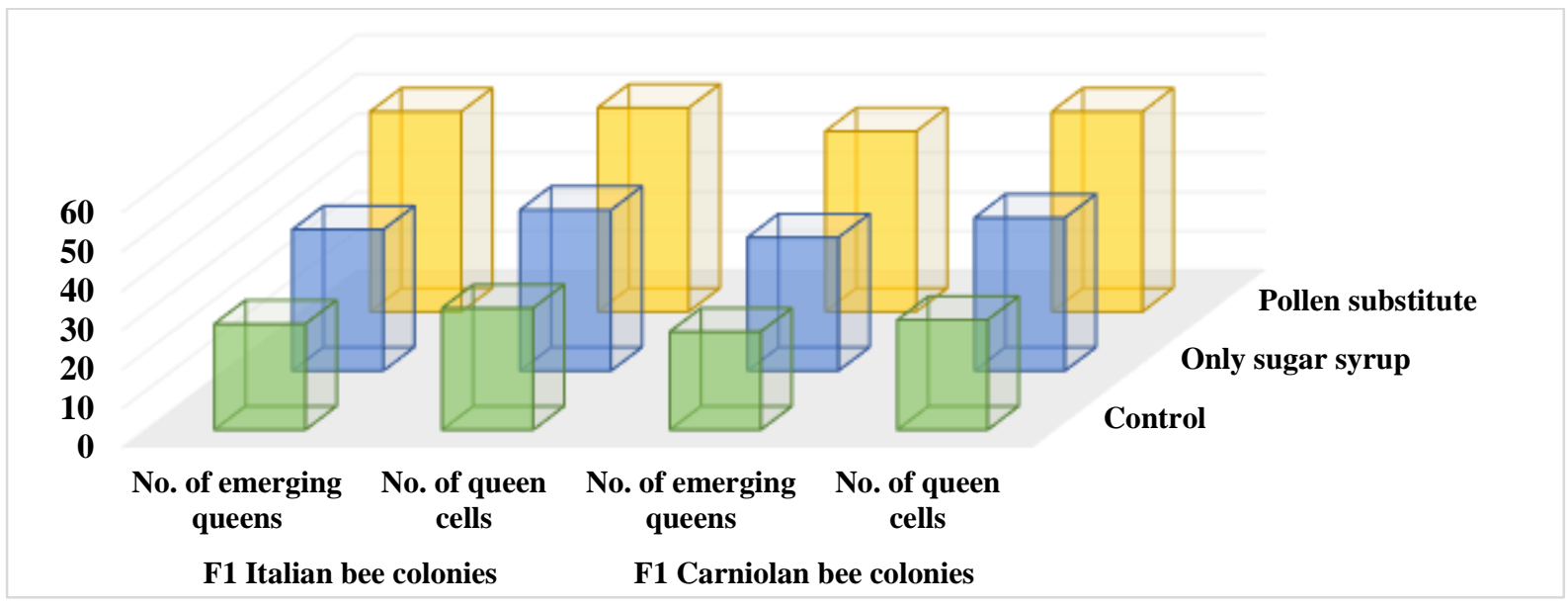

Fig 2. Effect of wintering and feeding treatments on queen rearing during March 2014

\section{Conclusion}

The obtained results indicated that F1 Italian bees is more better than F1 Carniolan bees in all tested queen rearing parameters (number of queen cells; length of queen cells; number of emerging new queens and queens fresh weight) during the two years of study. Data also indicated that feeding honey bee colonies with pollen substitute and sugar syrup affected positively on all queen rearing parameters and gave a good morphological virgin queens.

\section{References}

Abd El-Wahab, T.E.; Ghania, A.M.M. and Zidan, E.W.(2016) Assessment a new pollen supplement diet for honey bee colonies and their effects on some biological activities. J. of Agricultural Technology, 12(1):55-62
Dastouri, M. R. and Sis, N.M., (2007) The effect of replacement feeding of some protein sources with pollen on honey bee population and colony performance. Journal of Animal and Veterinary Advances, 6(11): 1258-1261.

El-Waseef, R. A. (2002): Ecological and physiological studies on honeybee colonies under different environmental conditions. M. Sc. Thesis, Fac. of Agric., Cairo Univ.

Ismail, A. A. (2001): Effect of some natural substances on the activity and some products of honeybee. M. Sc. Thesis, Fac. Agric., Mansoura Univ.

Krol, A.; Hartwig A.; Topolska G. (1992): Quality of queens reared in colonies receiving suger supplemented with vitamin B. Pszczel. Zesz. Nauk., 36:32-42.

Laidlaw, H.H. Jnr. 1979. Contemporary queen rearing. Dadant and Sons Inc.,Illinois, USA. 
Manning, R. (2001) Fatty acids in pollen: a review of their importance to honeybees. Bee World, 82:60-75.

Mahbobi, A. ; Farshineh-Adi M ; Woyke J, Abbasi S.( 2012) Effects of the age of grafted larvae and the effects of supplemental feeding on some morphological characteristics of Iranian queen honey bees (Apis mellifera meda skorikov, 1929). Journal of Apicultural Research, 56(1): 93-98.
MORSE, R A (1979) Rearing queen honey bees. Wicwas Press; Ithaca, NY, USA; 128 pp.

Standifer, L. N.; Owens, C. D.; Mills, J. P. and Levin, M. D. (1973) Supplementary feeding of honey bee colonies in Arizona. Am. Bee J. 113: 298-301.

Shoreit, M. N.; M. H. Hussen; M. O. M. Omar and M. F. Abdel-Rahman (2002): Brood rearing of the honeybee colony individuals and their activities in Assiut region. Egypt J. of Agric. Res., 80(1): 83-103. 